\title{
The Analysis of Electroencephalography Requests in Clinical Neurophysiology Department
}

\author{
Klinik Nörofizyoloji Bölümünde Elektroensefalografi İstemlerinin Analizi
}

\author{
Mahmut Bilal ÇAMAN, Vedat Semai BEK, Yasemin ÜNAL, Gülnihal KUTLU
}

Mugla Sitk1 Koçman University, School of Medicine, Department of Neurology, Muğla

$\overline{\mathbf{O z z}}$

Geçici bilinç kaybı (LOC) acil servis başvuruları içinde önemli bir yere sahiptir. Bu sebeple LOC etiyolojisini tanımlamak çok önemlidir. Bu çalışmada istek yapan klinisyenin ihtiyaçlarının karşılanıp karşılanmadığını değerlendirmek için poliklinik elektroensefalografi (EEG) kayıtlarımızı retrospektif olarak inceledik. Polikliniğimizdeki 01.07.2017 - 01.07.2018 arasındaki EEG kayitları incelendi. EEG'lerin 1015'i genel nöroloji uzmanları (\%70.05), 355'i epilepsi uzmanları (\%24.5) ve 79'u diğer bölümler (5.5) tarafindan istendi. Psikiyatri bölümü; diğer bölümler içinde üçte bir oranla çoğunluktaydı. 1449 EEG'den 281 'i anormaldi (\%19.4). EEG kaydı sırasında sadece üç hasta nöbet geçirdi. EEG kayıt istemi için ön tanı; 829 hastada (\%57.2) epilepsi, 257 hastada (\%17.8) senkop, 12'sinde baş ağrısı (\%0.8), 12 'sinde vertigo (\%0.8), 71'inde bilişsel işlev bozukluğu (\%4.9), 16 'sında uyku bozukluğu (\%1.1), 18'inde intrakraniyal kitle lezyonu (\%1.0), 54'ünde serebrovasküler hastalıklar (\%3.7), 26 'sında zihinsel durum değişikliği (\%73.3) ve 15 hastada (\%1.0) ensefalitti. Epilepsi ön tanısı ile yapılan kayıtlarda normal EEG kaydı oranı \%76.5 idi. Epilepsi ön tanısı olan hastaların $\% 45.1$ 'inde $\mathrm{keskin} /$ diken, \%41.5'inde fokal/jeneralize yavașlama ve \%11.8'inde zemin aktivitesinde yavaşlama anormallikleri bulundu. Genel olarak anormallik yüzdesi diğer bölümlerin aksine $(\% 82.1)$, genel nörologlar (\%76.0) ve epilepsi uzmanları (\%76.9) tarafindan talep edilen EEG'lerde benzerdi. Sonuç olarak; EEG bir tarama testi olarak yorumlanmamalıdır, bilinç kaybı epizodu sırasında hastaların detayları ve klinik özellikleri paha biçilmez bir öneme sahiptir, EEG kaydı isteminden önce ön tanı tekrar tekrar değerlendirilmelidir.

Anahtar Kelimeler: EEG, Epilepsi, Nöbet, Senkop

\section{Introduction}

Transient loss of consciousness (LOC) accounts for almost $3 \%$ of all emergency department attendances. Defining the etiologies is very important. Over $90 \%$ of presentations are due to epileptic seizures, syncope or psychogenic nonepileptic seizures (1). Unless the paroxysmal event takes place in the setting of videoelectroencephalography (vEEG) unit, there is a need for a gold standard diagnostic test, which we do not have. The diagnosis of epilepsy is made primarily on clinical grounds, but clinical criteria alone may not

\begin{tabular}{|c|c|}
\hline & ORCID No \\
\hline Mahmut Bilal ÇAMAN & 0000-0001-7956-5677 \\
\hline Vedat Semai BEK & 0000-0003-4913-976X \\
\hline Yasemin ÜNAL & 0000-0002-6110-9558 \\
\hline Gülnihal KUTLU & 0000-0002-9325-4151 \\
\hline Başvuru Tarihi / Received: & 10.06 .2020 \\
\hline Kabul Tarihi / Accepted : & 02.05 .2021 \\
\hline Adres / Correspondence : & Mahmut Bilal ÇAMAN \\
\hline \multicolumn{2}{|c|}{$\begin{array}{l}\text { Mugla Sitkı Koçman University, School of Medicine, Department } \\
\text { of Neurology, Muğla }\end{array}$} \\
\hline e-posta / e-mail $\quad:$ & mbilalcaman@gmail.com \\
\hline
\end{tabular}

\begin{abstract}
Transient loss of consciousness (LOC) has an important place in emergency applications. Therefore, it is very important to define the etiology of LOC. In this study, we retrospectively analyzed our outpatient electroencephalography (EEG) records to evaluate whether the clinician ordering the test had a fulfilling result. EEG recordings between 01.07.2017 to 01.07.2018 in our outpatient clinic were reviewed. 1015 of EEGs were ordered by general neurologists (70.05\%), 355 by epilepsy specialists $(24.5 \%)$ and 79 by other departments $(5.5 \%)$. The Department of Psychiatry was leading among other departments by one third. 281 out of 1449 EEGs were abnormal (19.4\%). Only three patients had a seizure during EEG recording. Preliminary diagnosis for EEG record request were epilepsy in 829 patients $(57.2 \%)$, syncope in 257 patients $(17.8 \%)$, headache in $12(0.8 \%)$, vertigo in $12(0.8 \%)$, cognitive dysfunction in $71(4.9 \%)$, sleep disorder in $16(1.1 \%)$, intracranial mass lesion in 18 (1.0\%), cerebrovascular diseases in 54 (3.7\%), altered mental status in $26(73.3 \%)$ and encephalitis in 15 patients $(1.0 \%)$. Normal EEG recording results were $76.5 \%$ in the recordings with preliminary diagnosis of epilepsy. Abnormalities found in patients with preliminary diagnosis of epilepsy patients were sharp/spike in $45.1 \%$, focal/generalied slowing in $41.5 \%$ and background slowing in $11.8 \%$. Overall abnormality percentage was similar in EEGs requested by either general neurologists $(76.0 \%)$ or epilepsy specialists (76.9\%) but not by other departments (82.1\%). As a result; EEG should not be interpreted as a screening test, patients' details and clinical features during loss of consciousness episode have a priceless importance and preliminary diagnosis should be re- and reevaluated before EEG recording request. Keywords: EEG, Epilepsy, Seizure, Syncope
\end{abstract}

be sufficient for either diagnosis or determining the classification. On the other hand, the interictal EEG on its own cannot diagnose or exclude epilepsy and cannot indicate prognosis independently or the likelihood for seizure relapse after discontinuation of antiepileptic drugs (AEDs) (2).

Although interictal findings are valuable in EEG, interictal epileptiform discharges in individuals without a history of seizure can be found and it is confusing. How EEG is interpreted or how much efficiently the EEG used is a matter of question in the outpatient clinics? How often can EEG findings support the preliminary diagnosis should be known by the clinician before ordering an EEG record?

We retrospectively analyzed our outpatient EEG records to evaluate whether the clinician ordering the test had a fulfilling result.

\section{Material and Method}

Ethics committee approval was obtained from Muğla Sitkı Koçman University Human Researches Ethics Committee (02.06.2020/71). EEG recordings between 01.07.2017 to 01.07.2018 in our outpatient 
clinic were reviewed. Inclusion criteria was limited with age restriction that EEGs of patients below 18 were not included. Ordering clinicians were classified as general neurologist, epilepsy specialist and other departments. All recordings were reviewed by two epilepsy specialists. All were classified as normal, or abnormal. Abnormal recordings were grouped as having sharp/spike waves, focal or generalized slowing, and background slowing. Cardiac arrhythmias were also noted. Preliminary diagnoses were epilepsy, syncope, headache, vertigo, cognitive dysfunction, sleep disorders, cerebrovascular disease, intracranial mass lesion, altered mental status and encephalitis. Percentage values were evaluated.

\section{Results}

The total number of EEG recordings was 1449. Gender distribution was even with 726 female and 723 male patients. Mean age was 43.9 years. 1015 of EEGs were ordered by general neurologists (70.05\%), 355 by epilepsy specialists $(24.5 \%)$ and 79 by other departments $(5.45 \%)$ (Figure 1$)$. The Department of Psychiatry was leading among other departments by one third. 281 out of 1449 EEGs were abnormal (19.4\%). Only three patients had a seizure during EEG recording. Preliminary diagnosis for EEG record request were epilepsy in 829 patients $(57.2 \%)$, syncope in 257 patients $(17.8 \%)$, headache in $12(0.8 \%)$, vertigo in 12 $(0.8 \%)$, cognitive dysfunction in $71(4.9 \%)$, sleep disorder in $16(1.1 \%)$, intracranial mass lesion in 18 $(1.0 \%)$, cerebrovascular diseases in $54(3.7 \%)$, altered mental status in $26(73.3 \%)$ and encephalitis in 15 patients $(1.0 \%)$.

Normal EEG recording results were $76.5 \%$ in the recordings with preliminary diagnosis of epilepsy. These were $96.5 \%$ in syncope, $75 \%$ in headache,

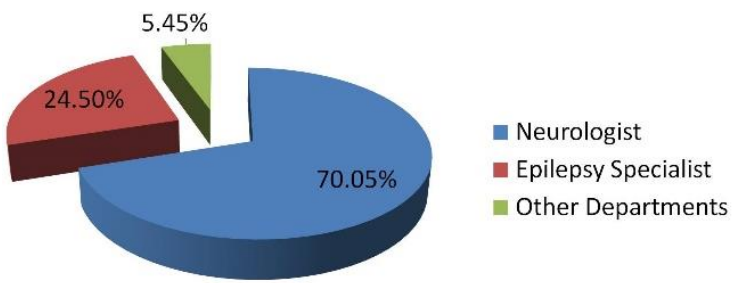

Figure 1. Percentage of specialists ordering EEG

$100 \%$ in vertigo, $88.7 \%$ in cognitive dysfunction, $87.5 \%$ in sleep disorders, $60 \%$ in intracranial mass lesion, $75.9 \%$ in cerebrovascular diseases, $65.3 \%$ in altered mental status and $73.3 \%$ in encephalitis (Figure 2). Abnormalities found in patients with preliminary diagnosis of epilepsy patients were sharp/spike (Interictal Epileptiform Discharges=IED) in $45.1 \%$, focal/generalied slowing in $41.5 \%$ and background slowing in $11.8 \%$. Overall abnormality percentage was similar in EEGs requested by either general neurologists $(76.0 \%)$ or epilepsy specialists (76.9\%) but not by other departments $(82.1 \%)$.

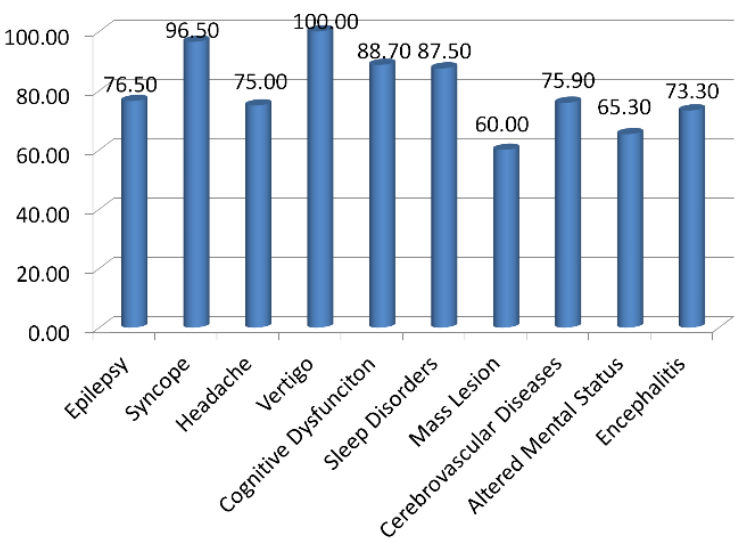

Figure 2. Percentage of normal EEG recording relation the preliminary diagnoses

\section{Discussion}

An EEG, which has been used for neuroimaging purposes for nearly a hundred years, was first recorded on animals by Richard Canton in 1875 (3). The first record on humans was in 1924 and was recorded by the German psychiatrist Hans Berger. Alpha rhythm and a relationship with alpha rhythm and eye closure were also described by Hans Berger (3). In the 1930s, studies focused on the relationship between epilepsy and EEG. Interictal patterns and ictal patterns; generalized and focal epileptiform discharges, were defined in these years by Gibbs, Lennox and Jasper (4). For the placement of electrodes on the scalp, a 10-20 system was developed in 1958 and years later, the International Federation of Clinical Neurophysiology recommended the use of the 10-20 system in recording (3). The years after the Second World War have been quiet for EEG. Along with technological developments, EEG has been an indispensable tool for neuroimaging in recent years (5).

EEG waves are formed by postsynaptic potentials in the cerebral cortex (6). These waves are recorded as negative if the ion entering the cell has a positive potential, and positive if the ion entering the cell is negatively charged (6). These discharges can give an idea to the clinician about the diagnosis and prognosis of the disease, in many diseases such as epilepsy, syncope, cognitive dysfunction, sleep disorders, and encephalitis. For this reason, in this study we examined the EEG records in our clinic.

Our analysis showed that the vast majority of EEGs $(70 \%)$ were requested by the general neurology outpatient clinic. This can be explained by the fact that the number of general neurology outpatient clinics are higher than in other areas. As a preliminary diagnosis, the most "epilepsy" (57.2\%) was written in EEGs. It was followed by "syncope" with $17.7 \%$. 
Of the total 829 EEG requested with a preliminary diagnosis of epilepsy, 195 were pathological $(23.5 \%)$. 88 of them had interictal epileptiform discharges. At $11 \%$, ground activity was slow. Epileptic seizures were observed in 3 patients during EEG recording.

In focal symptomatic epilepsies usually single high voltage spike wave, sharp wave (prominent after coming slow wave), mono- or polymorphic delta and vertical asymmetry as a rule. In idiopathic generalized epilepsies there is usually more than one focus of low voltage fast spikes or sharp waves with after coming slow (2). On the other hand, IED can be found in individuals without seizures. The detection of IED in such persons raises questions regarding the probability of future seizures and whether that probability justifies treatment with AEDs or restrictions of activities such as driving (7).

Repeated EEG studies may be useful. $56 \%$ of patients with a positive history of epilepsy had a specific discharge in the first EEG (8). This increases to $92 \%$ with three EEGs. Most studies have shown that an epileptiform discharge is predictive of seizure recurrence. In presence of epileptiform discharge, the recurrence risk is approximately double what would be predicted after normal EEG (9).

Although EEG abnormalities were reported with syncope, these results should be interpreted cautiously (10).

Early and late myoclonic or tonic contractions associated with syncope can be confused with epileptic seizure (11). Early contractions are caused by cerebral hypoperfusion, while late contractions are caused by cerebral reperfusion (12). EEG is very important for differential diagnosis in these patients.

Vasovagal hyperactivity leads to bradycardia or sinus arrest and causes syncope. Maneuvers such as compression on the eye can cause vasovagal hyperactivity (11). Since syncope and epileptic seizures can be confused clinically, EEG is important in the differential diagnosis.

Ictal bradycardia or asystole can cause syncope during a seizure $(12,13)$. If pallor, atony, LOC or early myoclonic contractions are observed clinically during the seizure, ictal bradycardia and asystole should be suspected (12). In the EEG recorded during this period, ictal discharges may continue or a diffuse slowing can be observed (12). Ictal asystole should be considered in cases of Sudden Unexpected Death in Epilepsy (SUDEP) (13).

EEG is an auxiliary examination to exclude epilepsy in patients presenting with LOC and syncope. In addition, EEG should be used to determine the etiology of syncope. In our analysis, pathology was determined in 9 of the 257 EEG requested by pre-diagnosis of syncope (3.5\%). 6 of them observed focal/generalized slow waves, while 2 records observed slow ground activity. In 1 record, IED was detected.
EEG is an auxiliary examination in the diagnosis and follow-up of dementia. The disruption of cortical networks responsible for cognitive functions causes EEG abnormality (14). Slowing in ground activity is associated with decreased cognitive functions. In addition, focal abnormalities, spike-wave complexes can be observed in dementia (15). EEG might help to differentiate dementia types (15).

EEG is a guiding test in many diseases other than epilepsy, dementia and syncope. For example; headaches, cerebrovascular diseases, sleep disorders and encephalitis. EEG can be used in differential diagnosis rather than diagnosis of these diseases.

In conclusions; EEG should not be interpreted as a screening test. It should be seen as an aid to diagnose in epilepsy, syncope, dementia and many other diseases. Patients' details and clinical features during LOC episode have a priceless value. This should be evaluated first for diagnosis. Preliminary diagnoses should be re- and reevaluated before EEG recording request.

Ethics Committee Approval: Ethics committee approval was obtained from Muğla Sitkı Koçman University Human Researches Ethics Committee (02.06.2020/71).

\section{References}

1. Wardrope A, Newberry E, Reuber M. Diagnostic criteria to aid the differential diagnosis of patients presenting with transient loss of consciousness: Asystematic review. Seizure. 2018;61:139-48.

2. Koutroumanidis M, Smith S. Use and abuse of EEG in the diagnosis of idiopathic generalized epilepsies. Epilepsia. 2005;46 (Suppl 9):96-107.

3. Kerry HL, Patrick C. Handbook of clinical neurology, vol. 160 (3rd series), clinical neurophysiology: basis and technical aspects. Elsevier, 2019.

4. Stone JL, Hughes JR. Early history of electroencephalography and establishment of the American Clinical Neurophysiology Society. J Clin Neurophysiol. 2013;30:28-44.

5. Robin K, Modern Electroencephalography. J Neurol. 2012;259:783-9.

6. 6. Hai C, Mohamad ZK, Electroencephalography in epilepsy evaluation. Continuum (minneap minn). 2019;25(2, epilepsy):431-53.

7. So EL. Interictal epileptiform discharges in persons without a history of seizures: what do they mean? J Clin Neurophysiol. 2010;27(4):229-38.

8. Badry R. Latency to the first epileptiform activity in the EEG of epileptic patients. Int J Neurosci. 2013;123(9):646-9.

9. Wirrell EC. Prognostic significance of interictal epileptiform discharges in newly diagnosed seizure disorders. J Clin Neurophysiol. 2010;27(4):239-48.

10. Heyer GL. Syncope is associated with electroencephalography changes. Clin Neurophysiol. 2018;129(7):1496-7.

11. Philippe G, Anna S, Jean MD, et al. Video EEG in syncopal attack due to ocular compression in an adolescent mistreated for epilepsy. Epileptic Disord. 2007;9(2):174-8.

12. Vi-Huong NM, Claude A, Vera D, et al. Characterization of seizure-induced syncopes: EEG, ECG and clinical features. Epilepsia. 2014;55(1):146-55

13. Michael B, Dawood D, Amir A, ve ark. Ictal asystole and ictal syncope: insights into clinical management. Circ Arrhythm Electrophysiol. 2015;8(1):159-64. 
14. Raffaele N, Luca S, Viviana V, et al. Usefulness of EEG techniques in distinguishing frontotemporal dementia from alzheimer's disease and other dementias, dis markers. 2018;2018:6581490.
15. Borislav R, Ratimir P, Anja G, et al. EEG analysis and spect imaging in alzheimer's disease, vascular dementia and mild cognitive impairment. Psychiatria Danubina. 